Citation: S. Trestini, A. Stiletto, S. Stranieri (2020) Price Determinants of Sparkling Wine in Poland: Does Reputation Really Matter?. Wine Economics and Policy 9(1): 73-84. doi: 10.36253/ web-8018

Copyright: (C) 2020 S. Trestini, A. Stiletto, S. Stranieri. This is an open access, peer-reviewed article published by Firenze University Press (http:// www.fupress.com/wep) and distributed under the terms of the Creative Commons Attribution License, which permits unrestricted use, distribution, and reproduction in any medium, provided the original author and source are credited.

Data Availability Statement: All relevant data are within the paper and its Supporting Information files.

Competing Interests: The Author(s) declare(s) no conflict of interest.

\section{Original Research Article \\ Price Determinants of Sparkling Wine in Poland: Does Reputation Really Matter?}

\author{
Samuele Trestini ${ }^{1, *}$, Alice Stiletto ${ }^{1}$, Stefanella Stranieri ${ }^{2}$ \\ ${ }^{1}$ Department of Land, Environment, Agriculture and Forestry, University of Padova, \\ Padova, Italy. ${ }^{*}$ Corresponding author \\ ${ }^{2}$ Department of Environmental Science and Policy, University of Milan, Milan, Italy \\ E-mail: samuele.trestini@unipd.it; alice.stiletto@unipd.it; stefanella.stranieri@unimi.it
}

\begin{abstract}
Due to the important worldwide growth of the sparkling wine sector in the last years, this research aims to explore the Polish sparkling wine retail market by applying a hedonic price model. Poland is the most important market in Eastern Europe, with a noticeable increase in wine consumption in recent years. Few researches have investigated the price premium of wine attributes in this area, while none of these concentrated their analysis on sparkling wines. The aim of this research is to apply a hedonic price model to estimate the effects of credence attributes and quality signals on sparkling wines sold in the Polish capital. Data were collected from 35 retail stores in Warsaw. Findings suggest that collective reputation linked to designation of origin is the variable that most affects the price, followed by brand reputation and characteristics of the point of sale. The type of retailer has a significant effect on price: discounts and supermarkets imply a price decrease with respect to hypermarkets, whereas specialised shops charge a premium. Moreover, we explore the presence of wine with Italian sounding names: this positively affects wine price, confirming the role of imitations stressed in the recent literature.
\end{abstract}

Keywords: hedonic price model, Poland, sparkling wine, premium price.

\section{INTRODUCTION}

The European Union is the world's biggest wine producer, with around $60 \%$ of the total (European Commission, 2015). Although global wine production in 2018 reached its highest value since 2000 ( 292 million hectolitres, representing a $17 \%$ increase compared to 2017$)^{1}$ it should be noted that 2018 marked a halt of the global growth in wine consumption precisely because of a stabilization in the main European producing countries, which are traditional consumer countries, as well as a slight decrease in China and the United Kingdom [1].

Considering the world wine trade, 2018 showed a modest growth in terms of volume (+ $0.4 \%)$ and value (+1.3\%) compared with 2017 (Table 1). The spar-

\footnotetext{
${ }^{1}$ In 2017 very difficult weather conditions affected wine production in many countries.
} 
Table 1. World wine trade.

\begin{tabular}{lcccc}
\hline \multirow{2}{*}{ Typology } & \multicolumn{2}{c}{2018} & \multicolumn{2}{c}{ Var. 2017-18 } \\
\cline { 2 - 5 } & volume & value & volume & value \\
\hline Bottled & $53 \%$ & $70 \%$ & $-8.0 \%$ & $-0.9 \%$ \\
Sparkling & $9 \%$ & $20 \%$ & $3.7 \%$ & $+6.3 \%$ \\
BiB(a) & $4 \%$ & $2 \%$ & $5.0 \%$ & $+15.7 \%$ \\
Bulk (>10L) & $34 \%$ & $8 \%$ & $-5.0 \%$ & $+3.8 \%$ \\
Total & $107.6 \mathrm{mln} \mathrm{hl} \mathrm{31.3} \mathrm{billion} €$ & $+0.4 \%$ & $+1.3 \%$ \\
\hline
\end{tabular}

Notes: (a) BiB, namely Bag in Box wines, identifies wines in containers holding more than 2 litres but not more than 10 litres. Source: OIV, 2019.

kling wine market, once again, saw the biggest growth in terms of both volume and value. Indeed, in 2018 the world sparkling wine trade accounted for $9 \%$ of the volumes traded and continued to increase in both volume $(+3.7 \%)$ and value $(+6.3 \%)$ compared with 2017. From 2013 to 2017, the value of sparkling wines traded on the international market gained 1.4 billion $€(+32 \%)$, more than double the rest of the wine sector $(+14 \%)$. Sparkling wines represent a significant share of exports, in terms of value, especially for Italy and France among EU countries, reaching $20 \%$ and $13 \%$ respectively in 2018 [1].

\subsection{Polish wine sector}

Nowadays, statistics show that non-traditional wine producing countries are experiencing a relevant increasing wine demand. Among EU countries, Poland has witnessed a significant increase in consumption in the last decade, with a variation of $33.3 \%$ from 2013 to 2018 (Table 2), due to a rising demand for wine and the growing culture of this beverage $[2,3]$.

According to Euromonitor [4], wine shares the alcoholic drinks market with two other product categories: beer (39.2 million $\mathrm{hl}$ in 2018) and spirits (2.9 million hl in 2018). Compared to wine, these categories have shown slower growth, of respectively $+5.4 \%$ for beer and $+3.2 \%$ for spirits compared to 2013. In the same period, sparkling wine grew $43.3 \%$ with a sales increase of $+11.8 \%$ in 2018, stronger than expected. This growth is related to the fact that consumers tend to choose it not only for special occasions but also throughout the year as a regular drink. The wine market in Poland can therefore be described as a growth sector, with a forecasted growth to 2023 (CAGR\%) of $+4.8 \%$ for still grape wine and $+11.5 \%$ for sparkling wine.

In addition, Poland is the largest economy in Eastern Europe and the second biggest importer in the area, accounting for $22.3 \%$ of total wine imports $[2,3]$.
Table 2. Wine consumption.

\begin{tabular}{|c|c|c|c|c|c|c|c|}
\hline & 2013 & 2014 & 2015 & 2016 & 2017 & 2018 & Var. 2013-18 \\
\hline \multicolumn{8}{|c|}{ Total volume (millions of hl) } \\
\hline Poland & 0.9 & 1.0 & 1.1 & 1.1 & 1.2 & 1.2 & $+33.3 \%$ \\
\hline Europe ${ }^{(a)}$ & 119.2 & 117.8 & 119.5 & 120.1 & 121.5 & 121.3 & $+1.8 \%$ \\
\hline World $^{(a)}$ & 242 & 241 & 243 & 244 & 246 & 246 & $+1.7 \%$ \\
\hline \multicolumn{8}{|c|}{ Per capita (l) } \\
\hline Poland & 2.9 & 3.1 & 3.2 & 3.4 & $3.5^{*}$ & $3.8^{*}$ & \\
\hline
\end{tabular}

Notes: (a) Countries with a wine consumption of more than 1 million hectolitres are included.

Source: OIV, 2018; OIV, 2019; * per-capita consumption data for 2017 and 2018 are estimated based on OIV, 2018; OIV, 2019.

Considering the trade channels, it emerges that the Polish retail sector has been very dynamic in the last decade, with a remarkable growth in the number of hypermarkets and supermarkets, even if the presence of small retail stores is still relevant. Indeed, alcoholic drinks' offtrade consumption in Poland is 6.3 times higher than ontrade consumption in 2018 [4]. The discount sector has the predominant share of wine sales, with wine imported from Portugal, Italy and Spain: these channels ensure sufficient quality products at a cheap price, thus encouraging their purchase by Poles. From 2010 to 2015, offtrade channels grew their share in Poland from 52.1\% to $72.8 \%$, while the on-trade channel had the smallest share of total volume sales of wine in Poland. This is due to the lack of tradition in consuming wine in foodservice outlets, such as bars, restaurants and hotels [4].

Seeking the reasons behind the growing interest of Poles in the wine sector, it emerges that it is due to the consumers trend of moving away from spirits towards lighter alcoholic drinks; indeed, after a period of decline in consumption, the purchase of wine has started to grow [5]. In particular, it is worth noting that the sparkling wine market is the most dynamic in the sector (as in many other countries) and has grown by 29.5\% in volume from 2012 to 2017, greater than other wines (+19.1\%).

In this scenario, it might be interesting to understand the contribution of product attributes in creating sparkling wine value on the Polish market; Poland not being a grape producer makes it an important case study to investigate. This could allow it to be understood how such a consolidated product category develops in a new market such as the Polish one (it should be remembered that the fact that Poland is not a grape producer leads to a not very strong wine tradition).

This paper aims to explore the sparkling wine market in Poland; in particular, this study applies a hedon- 
ic price model to investigate the effects of quality signals on the wine price. Due to the relative novelty of sparkling wine in Poland, taken as a mass product, we expect that credence characteristics, including reputational cues, will largely explain retailers' price variability. Various studies adopt this method in the wine sector, estimating the price effect both on the label information and sensorial evaluations $[5,6,7,8,9,10]$. However, from the literature analysis it emerges that there are limited applications of a hedonic model on sparkling wine [11]. This research, to the best of our knowledge, is the first application of a hedonic price model for sparkling wine in Eastern European countries. These countries can be defined as a "New buyers" and can be considered among the "New World" countries because they have litthe tradition of wine consumption and no tradition of its production [12].

\subsection{Hedonic research in the wine market}

Walking through an ordinary supermarket, a consumer may be surprised and, at the same time, confused by the huge number of different wines on the shelves. Wine, in fact, can be considered as a set of different characteristics, both sensory and objective and it is widely known that, for consumers, the purchase of this product is more complex than the choice for many other food goods, due to the large amount of different cues that can influence the purchase decision $[12,13]$. However, consumers use the attributes mentioned on the label, such as colour, vintage, appellation etc., (sensory and objective attributes) in addition to wine reputation when they wish to buy a product $[14,15]$. Thus, considering the wide variability in both types of wine and their prices, it could be interesting to understand how prices and wine characteristics are related: What are the specific effects of the different features mentioned on the bottle label, such as brand, vintage or different type of technology utilized for the production, on the prices? All these attributes have been used as the main variables in different studies on hedonic price models, pioneered in the early 1990s by Golan and Shalit [17] and by Oczkowski [18], precisely for answering to this question. Consumers can consider diverse sets of attributes at the time of purchase or they can assign different weights to product characteristics [19]. Orrego et al. [20] classified these attributes as intrinsic and extrinsic. The former can be considered as the essence of the product, such as vintage, grape variety, colour etc., while the latter are those characteristics that influence consumers' appreciation of the product but do not belong to the good itself (such as jury grade and cellaring potential, etc). Gener- ally speaking, consumers more familiar with a specific product tend to use more intrinsic characteristics, such as wine style, aroma, flavour and taste, whereas less familiar individuals mainly use extrinsic characteristics to evaluate the quality, such as price, packaging, labelling and brand name [21]. Consumer experience and the different type of information provided may influence the consumer's willingness to pay (WTP) a premium price for the quality signal; Poland being a young market, credence attributes [22] are going to be relevant in explaining wine prices.

Since obtaining information on quality is expensive for consumers [20] and the quality of a product cannot be known a priori (i.e., before purchase), customers can use other ways to infer it and, especially for wine, they can use reputation as a guarantee of quality [22, 23]. Reputation is an essential tool especially on the "Old World" market; indeed, it is common in the literature to divide the world into "Old World" countries, i.e. the traditional producers such as France, Italy, Spain etc., and "New World" countries, i.e. new producers, such as the United States, Australia, New Zealand etc. [12]. Orrego et al. [20] found that most hedonic research on the wine market was conducted for "New World" wines sold in "New World" countries; it emerged that, for these wines, rating (jury grade), vintage and place of origin have a strong and positive price premium (see for instance Manesme et al. 2019). Instead, on the "Old World" market the most important attributes that influence price are place of origin and reputation index. Many authors have studied the impact of reputation on wine price and linked them with consumers' choice. Among others, Schamel and Anderson [25], Schamel [26] and Costangiro and McCluskey [27] pointed out how producer's reputation plays a decisive role in determining the price of wines, by applying a hedonic price model on premium wines sold in Australia/New Zealand and the US, and on red wines in California. Caracciolo et al. [28] investigated, through a hedonic price model, the effect of private and collective reputation on wine price, analysing the wine purchases made by a panel of representative Italian families. Estimates based on quantile regression reveal that the effects of the two reputation strategies (private and collective) have different weights depending on the price range of the wines. While private reputation plays an important role in both low-priced and highpriced wines, collective reputation in terms of geographical denominations appears to be particularly important for high-priced wines. This is confirmed by Rossetto and Gastaldello [29] who found that wines in the higherprice range benefit from strong consumer loyalty. Verdonk et al. [30] highlighted that brand image and rep- 
utation play an important role in purchasing decisions, as well as advice, recommendations and expert reviews, and consumption occasion. To this extent Oczkowsky et al. [31] found that experts rating has an important effect in explaining prices.

Trestini et al. [11], instead, examined the impact of different product characteristics on sparkling wine price on the German market. They found that an Italian sounding name positively affects consumers' WTP just because of brand reputation. Within this context, the influence of the reputation of the iconic "Champagne" was bound to be studied. Lee and Sumner [32] investigated the effect of the term "Champagne" on sparkling wine in the US market. Their study evidenced that when the term "Champagne" is reported on the label of French wines (sold in the US) the price is much higher than other wines in the category, ceteris paribus. And when "Champagne" is reported on the label of American wines, without reflecting the region in France, the price is much lower than other comparable wines.

From the literature analysis on hedonic price, it emerges that, as previously reported, sensory and objective characteristics also play a role as explanatory variables of the model in order to evaluate the effects of quality attributes on wine prices. With regard to the former ones, which derive from the chemical components of wines such as aroma or acidity and bitterness levels etc. - i.e. strongly influenced by the production methods $[32 ; 33]-$, it should be noted that the first studies on this topic were conducted twenty years ago (see for instance Nerlove [10]). Combris et al. [8] highlighted that consumers are more likely to use objective features as quality signals, by applying a hedonic price model to different Bordeaux wines, while the quality of a particular wine can be explained by wine jury members on the basis of its sensory characteristics. Jones and Storchmann [35], Schamel and Anderson [25] and Benfratello et al. [36], among others, supported the central role of sensory variables on the price, thanks to the evidence derived from their hedonic price studies on different types of wines. Within this framework, certainly noteworthy is the article of Lecocq and Visser [37] that aimed to explore the effect of sensory and objective features on three different data sets (two on Bordeaux wines, and one on Burgundy wines). They found that the objective characteristics, directly revealed to the consumers on the labels, explain the major part of the price differences, while the subjective ones seem not to play an important role. Furthermore, wine prices are hardly affected by the jury grade assigned by professional wine tasters, which are closely linked to the sensory characteristics, as previously reported.

\section{MATERIAL AND METHODS}

\subsection{Data collection}

Data were collected by recording prices and wine attributes that a free-service customer could observe directly from the bottle on the shelves. The dataset contains observations on white sparkling wines and Champagne with and without geographical indication. Prices are identified in the currency that is used in Poland (PLN). It should be noted that the average monthly exchange with the euro was around 4.43 PLN in December, 4.36 PLN in January and 4.38 PLN in February. The current exchange with the euro (September 2019) is 4.26 PLN.

Since numerous studies reported that distribution channels have a significant effect on wine price (see for instance Rebelo et al. [14]), we selected different kinds of distribution channels (supermarkets, hypermarkets, discounts, specialised shops), both local and foreign, in order to understand wine premium price according to location, type and size of retailer. It was expected that the price in specialised shops would be higher than the others, while other aspects, such as the premium price in different areas of the city was unknown. It was otherwise supposed that the central area of the city (Środmieście) would have the highest prices in comparison to other locations.

Data were collected from December 2016 to February 2017. We interrupted the survey in the Christmas period (from December $15^{\text {th }}$ to January $10^{\text {th }}$ ) to avoid a biased effect on product selection and price promotions. The shops had been randomly chosen among the 18 districts of the city of Warsaw (Figure 1). A sample of 35 retailers were selected for the survey: 10 supermarkets, 10 hypermarkets, 12 discount stores and 3 specialised shops. This distribution takes into account the market share of different types of retailers ${ }^{2}$, with the aim of ensuring at least one observation per district. The list of shop types and their distribution among districts are reported in table 3 . The survey collected information on 1,095 references to sparkling wine.

\subsection{Model specification}

The hedonic price model is based on the hypothesis that each good is characterized by the entire set of attributes that define it in a unique way. Given that wine

\footnotetext{
${ }^{2}$ According to Euromonitor data, discounts have 33\% of wine market share in store-based retailing, hypermarkets have $16 \%$, supermarkets $40 \%$ and specialist shops $7.1 \%$.
} 
Table 3. Number of retailers by category distributed among districts.

\begin{tabular}{|c|c|c|c|c|c|}
\hline \multirow[b]{2}{*}{ Districts } & \multicolumn{5}{|c|}{ Retailers category } \\
\hline & $\begin{array}{l}\text { Super- } \\
\text { markets }\end{array}$ & $\begin{array}{l}\text { Hyper- } \\
\text { markets }\end{array}$ & Discounts & $\begin{array}{c}\text { Special- } \\
\text { ized } \\
\text { shops }\end{array}$ & Total \\
\hline$\overline{\text { Żoliborz }}$ & 1 & 1 & & & 2 \\
\hline Bemowo & & & 2 & & 2 \\
\hline Białołęka & 1 & & 1 & & 2 \\
\hline Bielany & & 1 & & & 1 \\
\hline Mókotów & & 1 & & 1 & 2 \\
\hline Praga Połnoc & & 2 & 1 & & 3 \\
\hline Praga Południe & 1 & 1 & & & 2 \\
\hline Rembertów & & & 1 & & 1 \\
\hline Środmieście & 4 & & & 1 & 5 \\
\hline Turgówec & 1 & & 1 & & 2 \\
\hline Ursus & & & 1 & & 1 \\
\hline Ursynów & & 3 & 2 & 1 & 6 \\
\hline Włochy & & & 1 & & 1 \\
\hline Wawer & 1 & & 2 & & 3 \\
\hline Wilanów & 1 & & & & 1 \\
\hline Wola & & 1 & & & 1 \\
\hline Total & 10 & 10 & 12 & 3 & 35 \\
\hline
\end{tabular}

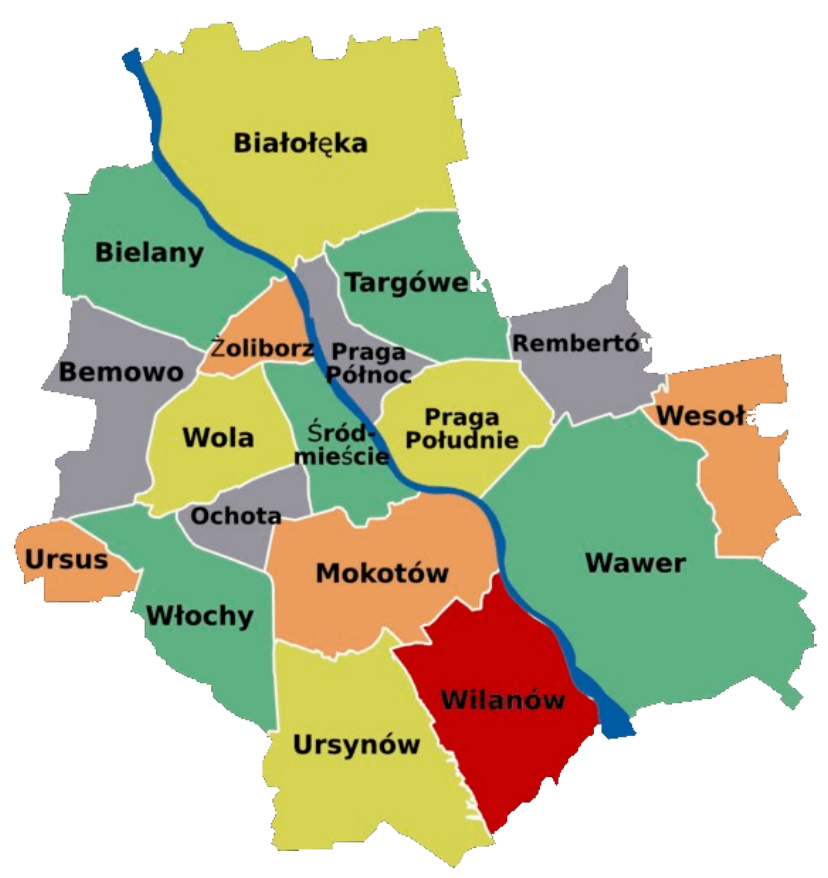

Figure 1. The 18 Districts of the city of Warsaw.

Although there is no theoretical basis for the functional form that should be applied, it should be remembered that the most used are the linear $[39,40]$, semilogarithmic [41, 10] and Box Cox linear [43].

As reported by León [43] in his comprehensive literature analysis of hedonic price, the Box Cox transformation [44] can be useful not only as a flexible functional form, but also as a tool to choose the best functional form among those applicable.

Following this method, also applied by Ferro and Benito Amaro [45] and Rossetto and Galletto [46], the transformation of the dependent variable, $\mathrm{Y}>0$, is:

$Y(\lambda)= \begin{cases}\frac{\left(Y^{\lambda}-1\right)}{\lambda} & \text { if }(\lambda \neq 0) \\ \ln (Y) & \text { if }(\lambda=0)\end{cases}$ of the $i^{\text {th }}$ product. Hence, hedonic prices are described as implicit prices of attributes and their analysis involves the regression of price with respect to the product characteristics. The partial derivative of the price function represents the marginal price of that attribute. Furthermore, the hypotheses of Rosen [39], which guarantee that observed price is the result of market equilibrium are: i) each level of $z$ attribute is used interchangeably to designate commodities of a given quality or specification; ii) there is a sufficiently large number of differentiated products available so that choice among various combinations of $z$ is continuous. We thus assume that this hypothesis is satisfied for wine by looking at price and attributes in the retail market. $\lambda$ being the transformed parameter of the dependent variable $(\mathrm{Y})$.

As specified by Box and Cox [44] it should be noted that since an analysis of variance is unchanged by a linear transformation (1) is equivalent to:

$Y(\lambda)= \begin{cases}Y^{\lambda} & (\lambda \neq 0) \\ \ln Y & (\lambda=0)\end{cases}$

By applying an OLS regression the log-linear functional form was shown to be preferable, in line with many 
other applications $[46,5,47]$. The OLS regression has to satisfy the hypothesis of homoscedasticity and no multicollinearity. Multicollinearity was checked through the VIF (Variance Inflation Factor): no variable in the model showed VIF greater than 5 [49]. The presence of heteroscedasticity was verified applying the Breusch-Pagan [50] and White tests [51]. We found a violation of the hypothesis of homoscedasticity with OLS regression. In order to solve the heteroscedasticity issue, we re-estimated the model with robust standard errors applying a Generalized Linear Model with the MLE estimator performed through IBM-SPSS 26.0. We then looked for the best functional form regression by evaluating McFadden's pseudo $\mathrm{R}^{2}$ after repeating the Box-Cox transformation. After application of the MLE estimator with robust standard error, the loglinear function form was confirmed to be the best one (McFadden's pseudo $\mathrm{R}^{2}=0.744$ ):

$\ln (\mathrm{P})=\beta_{0}+\Sigma \beta_{i} z_{i}+\varepsilon$

where $\ln (P)$ is the $\log$ of the price, $z_{i}$ is the $i$ attribute of the wine, $\beta_{i}$ are the estimated coefficients of the $z_{i}$ variables and $\varepsilon$ the random error. This form allows the percentage variation of the product price to be explained that is independently attributable to a specific characteristic.

The variables included in the model refer to objective and reputational characteristics of sparkling wine together with attributes linked to the retailer type and location. In order to understand the reputation effect on wine it was necessary to include in the model the variables of the main wine brands ${ }^{3}$ (Martini, Henkell and Moët Chandon are the principal brands on the shelves. In fact we took into account only the brands that have been observed at least 30 times during the data collection) and the collective brand of Designation of Origin (DO), namely the Appellations, (Asti, Champagne, Cremant, Cava, Prosecco DOC 4 , Prosecco DOCG are the most frequent in the dataset).

Our hypothesis is that the price is higher in central Warsaw: we considered Center as a variable that describes how important the location of the store is. As previously reported, the type of retailer can also influence the price, hence supermarket, spec_shop, hypermarket, discount variables have been attached.

\footnotetext{
${ }^{3}$ We chose to use the term "wine brand" to refer both to winery and company brands. Indeed, some companies may have different product lines and show either the company or winery name on the labels. The aim is to report the brand used by consumers to make their choice.

${ }^{4}$ Prosecco is classified as a white wine produced from Glera grapes that are grown in a specific area of two Italian regions (i.e. Veneto and Friuli Venezia Giulia). For the description of DOC and DOCG Prosecco see Trestini et al. [11]
}

Because of the recent expansion of foreign hypermarkets in Poland, we inserted the variable Nat_R, to express the nationality of the shop. From our survey, all the specialised shops are Polish, as are $80 \%$ of supermarket brands, $20 \%$ of discount and no hypermarkets.

Cembalo et al. [52] describe the so-called "Italian sounding" as a false evocation of the Italian origin of the products and, according to Trestini et al. [11], this phenomenon may have a positive effect on the wine price due to a misleading reputation perceived by consumers. Thus, Italian sounding variable was included in the model, considering also that this item is always measured when wine names include terms associated with Italian culture (e.g. Michelangelo, Raffaello, Veneziano).

Other quality attributes, such as Vintage (i.e. when $85 \%$ of grapes used to make the wine were harvested in the same year) and Traditional method (i.e. when the second fermentation took place in the bottle) are considered as dummy variables. We expect that these variables raise the price of wine. Indeed, from the study conducted by Vecchio et al. [34] it emerged that detailed information on the Champenoise, which is just another name for the Traditional method, is perceived as positive and increases WTP especially by young consumers. Brut, Dry and Sweet taste variables are also included to describe attributes. Furthermore, Promotion variable (i.e. when wine is sold at a discount price) had to be added, as well as Alcohol content. Finally, the variable Volume considers the effect of different bottle sizes. Table 4 reports descriptive statistics.

\section{RESULTS AND DISCUSSION}

The dependent variable of the model is represented by the log-price of a bottle ( $0.75 \mathrm{~L}$ in volume) of a sparkling wine with an alcohol content equal to $11 \%$. Reference baseline is assumed to be a wine without designation of origin or vintage specification, produced without second fermentation in bottle. This wine is sold in Warsaw, in a foreign-owned hypermarket (non-Polish) outside the central district. In addition, it is sold without any price discount. The wine format is $0.75 \mathrm{~L}$, at an average price of 32.77 PLN (around $€ 7.70$ ). Estimates are summarised in Table 5.

The estimated model well explains the observed price variability (Pseudo- $\mathrm{R}^{2}=0.744$ ); all the variables are statistically significant, with a p-value lower than 0.05 , except for Henkell, Asti, Cava, Traditional method and Sweet.

As supposed, due to their reputation, brands like Martini and Moët \& Chandon have a relevant and sta- 
Table 4. Sample descriptive statistics.

\begin{tabular}{|c|c|c|c|c|}
\hline Variable & Description & Type & N. obs & $\%$ \\
\hline \multicolumn{5}{|l|}{ Bottler nationality } \\
\hline Italy & & $\mathrm{D}$ & 310 & 28.3 \\
\hline France & & $\mathrm{D}$ & 260 & 23.7 \\
\hline Poland & & $\mathrm{D}$ & 22.6 & 22.6 \\
\hline Spain & & $\mathrm{D}$ & 150 & 13.7 \\
\hline Germany & & $\mathrm{D}$ & 54 & 4.9 \\
\hline Other_or & Other Origin & $\mathrm{D}$ & 73 & 6.7 \\
\hline Wine Brand & \multicolumn{4}{|c|}{ Company or winery brand, depending on the reported brand in the label. } \\
\hline Martini & & $\mathrm{D}$ & 73 & 6.7 \\
\hline Henekell & & $\mathrm{D}$ & 47 & 4.3 \\
\hline Moet & Moet\&Chandon & $\mathrm{D}$ & 37 & 3.4 \\
\hline \multicolumn{5}{|l|}{ Point of Sale } \\
\hline Special & Specialised shops & $\mathrm{D}$ & 55 & 5.0 \\
\hline Super & Supermarkets & $\mathrm{D}$ & 310 & 28.3 \\
\hline Disc & Discounts & $\mathrm{D}$ & 88 & 8.0 \\
\hline Nat_R & Polish retailer & $\mathrm{D}$ & 232 & 21.2 \\
\hline Center & Store located in Central district & $\mathrm{D}$ & 160 & 14.6 \\
\hline \multicolumn{5}{|l|}{ Appelations } \\
\hline Asti & Asti & $\mathrm{D}$ & 47 & 4.3 \\
\hline Champagne & Champagne & $\mathrm{D}$ & 175 & 16.0 \\
\hline Cremant & Cremant & $\mathrm{D}$ & 22 & 2.0 \\
\hline Cava & Cava & $\mathrm{D}$ & 118 & 10.8 \\
\hline Prosecco_docg & Prosecco Conegliano, Valdobbiadene, DOCG & $\mathrm{D}$ & 25 & 2.3 \\
\hline Prosecco_doc & Prosecco DOC & $\mathrm{D}$ & 170 & 15.5 \\
\hline Other_ita & Trento, Franciacorta, Oltrepò Pavese & $\mathrm{D}$ & 4 & 0.4 \\
\hline Other_fr & Clariette Die, Saumur & $\mathrm{D}$ & 7 & 0.6 \\
\hline \multicolumn{5}{|l|}{ Method } \\
\hline Traditional Method & & $\mathrm{D}$ & 134 & 12.2 \\
\hline \multicolumn{5}{|l|}{ Type } \\
\hline Vintage & Wine with grapes coming from the same harvest year & $\mathrm{D}$ & 20 & 1.8 \\
\hline Dry & Dry, Demi sec, Demi sweet, Extra dry & $\mathrm{D}$ & 305 & 27.9 \\
\hline Brut & Brut, Brut Nature, Brut Alb, Extra Brut & $\mathrm{D}$ & 323 & 29.5 \\
\hline Sweet & & $\mathrm{D}$ & 239 & 21.8 \\
\hline \multicolumn{5}{|l|}{ Sounding } \\
\hline Italian sounding & Bottle with wine name sounding as Italian & $\mathrm{D}$ & 200 & 18.3 \\
\hline \multicolumn{5}{|l|}{ Promotion } \\
\hline \multirow[t]{2}{*}{ Promotion } & & $\mathrm{D}$ & 82 & 7.5 \\
\hline & & & Mean & Std. Dev \\
\hline \multicolumn{5}{|l|}{ Volume } \\
\hline Volume & & $\mathrm{C}$ & 0.76 & 0.19 \\
\hline \multicolumn{5}{|l|}{ Alcohol } \\
\hline Alcohol & Alcohol content & $\mathrm{C}$ & 10.76 & 1.45 \\
\hline
\end{tabular}

Notes: $\mathrm{D}=$ dummy variable; $\mathrm{C}=$ continuous variable.

tistically significant premium price equal to $36.9 \%$ and 49.6\% respectively, while Henkell has no significant effect on wine price. This price premium is calculated in com- parison with the other brands (different from Martini, Henkell and Moët \& Chandon). It is widely reported in the literature $[26,52,25,10]$ that brand reputation has a 
positive and significant effect on wine purchase decision. Especially for those consumers who have scarce information about the quality of wine, the brand plays a positive and decisive role and consumers are willing to pay a higher price, because they trust brands, due to their reputation as a guarantee of high quality.

When it comes to the shop location, we find that a central position (Center) has a premium price $(+10.4 \%)$ if compared to those that are located in the periphery. These results seem to be mainly linked to the retailers' costs, which are higher in the central district and small specialised shops. Findings demonstrate that the type of shop can affect the product price: the specialised shops have higher prices (54.7\%), whereas Supermarkets (-5.1\%) and Discounts $(-35.0 \%)$ offer a discount when compared to hypermarkets, according to what was found by Trestini et al. [11]. Our results are consistent with those of $\mathrm{Di}$ Vita et al. [54]: they found that wine shops have a direct impact on price fixing, highlighting the presence of a premium price for high quality wines. Indeed, Cerjak et al. [55], who investigated sparkling wine purchasing and consumption behaviour among Croatian consumers, found that there are differences between consumer groups. Older consumers with good economic status are the staunchest sparkling wine consumers and often choose specialised shops and direct sale for their purchase, even if the price is higher. The higher price is largely explained by the different type of information provided. Boatto et al. [6] have shown that consumers are willing to pay for "tailor-made" information supplied by the retailer during the purchasing process in the specialised shops. They found that this premium is nearly $200 \%$ for wines without relevant quality signals and lower for quality wines. Polish specialised shops guarantee a premium price lower than that estimated in traditional wine consumer countries (i.e. Italy), perhaps suggesting a lower quality of service and product selection. The nationality of the retailer has a significant and positive effect when it is Polish (Nat_R), with a premium price of $16.5 \%$ compared to the non-Polish ones.

Poland variable is referred to the Polish nationality of the bottler of some wines, not produced with Polish grapes but made in Poland. Findings show that these products have a price discount of $61.6 \%$ when compared to other wines. Muller [56] assessed the effect of local brands on the premium price in Germany, rarely finding positive effects. In the case of Polish consumers, they cannot recognise Polish wine, and the discount price can be mainly related to low production costs. In fact, many of these products ( $77 \%$ of the wines investigated) apply Italian sounding wine names (Poland ${ }^{\star}$ Italian sounding), which guarantees these wines a price premium equal to
49.5\%. As reported by Trestini et al. [11], even though the wine has no declared origin, attaching an Italian sounding name to the bottle label makes the consumer think about the reputation of Italian quality. As stressed in the literature, Italian sounding can affect consumers' purchasing decision: they may interpret price as a quality signal, due to the asymmetric information [57]. Nowadays, in fact, the presence of Italian sounding names seems to be a confirmed tendency on the international food and beverage market; free riders have the opportunity to profit from the quality associated with this origin, due to the diversified supply of Italian sparkling wines. Indeed, the Italian origin of products does not bring to the mind of consumers an univocal and specific product, as happens in the case of French ones (for which there is a clear reference to Champagne), leaving room for imitations. European institutions do not limit the use of this kind of wine naming, which is regulated under the rules of trademarks. However, this result should be interpreted as an effect of misleading information given to an inexpert consumer, who places value on a name that emulates the positive reputation of the Italian food and beverage tradition. Moreover, we find that, except for Cava and Asti, all the designations of origin have significant and positive effects on price: as expected, the highest premium is attached to Champagne (+ 395.9\%), followed by Prosecco DOCG (+49.1\%), Cremant (+31.7\%) and Prosecco DOC $(+13.3 \%)$.

In addition, the other French appellations (other_fr) (e.g. Clairette de Die, Saumur) show a statistical significance in creating value in the estimated model $(+18.7 \%)$, as well as the other Italian designations of origin do $(+75.9 \%)$. DO, as often reported $[5,6,53]$ is a source of collective reputation closely related to consumers' perception of the quality of wine. This is particularly true when the place of production is far from the consumption area [58] and consumers have limited connections to wine producers. In this framework, Champagne has the greatest impact on price, but Prosecco DOCG, Prosecco DOC and the other Italian geographical indications, such as Trento, Franciacorta and Oltrepò Pavese, are also considered valued products, considerably increasing the price. As reported by Onofri et al. [59], the different sensitivity to price variations is confirmed by the fact that consumers of Prosecco DOCG express a preference for the product characteristics (brand and taste). This can be explained by a greater "loyalty to the product" of the Prosecco DOCG consumers than the Prosecco DOC purchasers.

Traditional method attribute does not significantly affect the price with respect to the Charmat method of production: this feature being generally linked to specific 
Table 5. Hedonic model estimates.

\begin{tabular}{|c|c|c|c|c|}
\hline Variable & $\beta$ & Std. Err. & Sign. & $\begin{array}{c}\% \text { Price } \\
\text { Premium }^{(a)}\end{array}$ \\
\hline Constant & 0.325 & 0.165 & 0.050 & \\
\hline \multicolumn{5}{|l|}{ Wine Brand } \\
\hline Martini & 0.315 & 0.038 & 0.000 & $+36.9 \%$ \\
\hline Henkell & 0.019 & 0.045 & 0.677 & n.s. \\
\hline Moet & 0.404 & 0.059 & 0.000 & $+49.6 \%$ \\
\hline \multicolumn{5}{|l|}{ Point of Sale } \\
\hline Special & 0.439 & 0.070 & 0.000 & $+54.7 \%$ \\
\hline Super & -0.052 & 0.020 & 0.008 & $-5.1 \%$ \\
\hline Disc & -0.429 & 0.043 & 0.000 & $-35.0 \%$ \\
\hline Center & 0.099 & 0.041 & 0.014 & $+10.4 \%$ \\
\hline Nat_R & 0.153 & 0.042 & 0.000 & $+16.5 \%$ \\
\hline \multicolumn{5}{|l|}{ Bottler Nationality } \\
\hline Poland & -0.954 & 0.065 & 0.000 & $-61.6 \%$ \\
\hline \multicolumn{5}{|l|}{ Sounding } \\
\hline Poland ${ }^{\star}$ Italian sounding & 0.424 & 0.064 & 0.000 & $+52.5 \%$ \\
\hline \multicolumn{5}{|l|}{ Appelations } \\
\hline Asti & 0.077 & 0.061 & 0.208 & n.s. \\
\hline Champagne & 1.602 & 0.051 & 0.000 & $+395.9 \%$ \\
\hline Cremant & 0.277 & 0.062 & 0.000 & $+31.7 \%$ \\
\hline Cava & -0.026 & 0.066 & 0.697 & n.s. \\
\hline Prosecco_Docg & 0.401 & 0.058 & 0.000 & $+49.1 \%$ \\
\hline Prosecco_Doc & 0.125 & 0.032 & 0.000 & $+13.3 \%$ \\
\hline Other_It & 0.601 & 0.269 & 0.026 & $+75.9 \%$ \\
\hline Other_Fr & 0.173 & 0.067 & 0.009 & $+18.7 \%$ \\
\hline \multicolumn{5}{|l|}{ Method } \\
\hline Traditional method & 0.085 & 0.070 & 0.227 & n.s. \\
\hline \multicolumn{5}{|l|}{ Type } \\
\hline Sweet & -0.055 & 0.041 & 0.183 & n.s. \\
\hline Brut & 0.166 & 0.029 & 0.000 & $+18.0 \%$ \\
\hline \multicolumn{5}{|l|}{ Vintage } \\
\hline Vintage & 0.204 & 0.099 & 0.040 & $+22.0 \%$ \\
\hline \multicolumn{5}{|l|}{ Promotion } \\
\hline Promotion & -0.100 & 0.033 & 0.002 & $-9.6 \%$ \\
\hline \multicolumn{5}{|l|}{ Volume } \\
\hline Volume & -0.219 & 0.082 & 0.008 & $-15.1 \%$ \\
\hline \multicolumn{5}{|l|}{ Alcohol } \\
\hline Alcohol & -0.037 & 0.015 & 0.013 & $-3.6 \%$ \\
\hline$\overline{\text { Adjusted } \mathrm{R}^{2}}$ & & & 0.744 & \\
\hline N. Obs & & & 1,095 & \\
\hline
\end{tabular}

Notes:(a) Adjustments made according to Kennedy [60].

DO, we can argue that on the Polish market it does not affect retail price.

Euromonitor [4] reported that the tastes of Polish consumers have changed significantly in the last peri- od: in line with the growing wine culture, consumers are moving from sweet and herbal wines to dryer ones. The results are thus in line with expectations. Brut type increases the price by $18.0 \%$, if compared to the dry categories (Dry, Demi sec, Demi sweet, Extra dry). This is in line with what was found by Rossetto and Galletto [46] and justified by a general trend in modern consumption.

Vintage wines have an important premium price $(+22.0 \%)$, as also found by Menesme et al. 2019. As expected, wines with Promotion have a statistically significant discount, equal to $-9.6 \%$.

Regarding the Alcohol content, we found that it is negatively correlated with the price: a $1 \%$ increase in alcohol content (e.g. passing from 11 to $12 \%$ ) brings a $3.6 \%$ price decrease. This result is contrary to and with a lower estimated effect to what was found by Rossetto \& Galletto [46] for rosé wines on the Italian market. Our opposite results may be justified by the young wine consumers in Poland who, ceteris paribus, may prefer wines with slightly lower alcohol content.

\section{CONCLUSIONS}

This paper aims to estimate the hedonic price model by comparing the impact of different characteristics on sparkling wines' prices in Poland, also including the point of sale, with specific attention to reputational attributes.

The results confirm that the retail wine market in Poland assigns a price premium to quality attributes coherently with the estimated model in a traditional wine consumers market. The point of sale plays an important role in affecting the price, confirming the expected signs: central areas of Warsaw have a small but relevant and positive influence on price; discounts and supermarkets imply a decrease of price with respect to hypermarkets. Specialised shops have a price premium that is lower than that observed in traditional consumer markets (e.g. Italy) where service at the point of sale can add a price premium that is four time higher than in Poland.

Despite the fact that Polish consumers still choose low-priced wines [4], reputational variables - wine brand (brand reputation) and DO (collective reputation) - have a big impact on price. Well-known wine brands guarantee a relevant price premium at retail level, because of huge investments made by private companies. At the same time, Polish consumers are starting to pay more attention to collective brands, above all sparkling wines with DO from Italy, France and Spain. A new wine mar- 
ket, like Poland, is characterised by a relevant presence of quality wines, with a growing importance of New World wines and a high number of medium range prices. International sparkling wine in a new wine market is currently dominated by Old World producers, but the access to these new markets is introducing new forces that justify the fact that the market for sparkling wine is gradually changing, both in Poland and Europe. Sparkling wine is increasingly competitive in the overall wine sector, and exports of Italian, Spanish and French wines prove this trend. Almost all the DO obtain a relevant price premium that justifies the efforts towards the achievement of a specific quality and identity that allows the /building of a collective reputation with a recognised value on the market. In this context, the attempt to profit from other collective reputations, like using Italian sounding names, finds room for growth when consumers have limited knowledge about how to select quality wines. Information asymmetry is relevant in evaluating this market situation, as well as confirming that the majority of consumers are non-experts and risk-averse and tend to look for reputational signals to make their choice.

The estimated hedonic model can be useful for determining the opportunities for sparkling wines in this new wine market, especially for producers and all operators in the supply chain. These results, in fact, may support producers and retailers in defining the price at which sparkling wines can be placed on the Polish market. Moreover, they may be useful for understanding the dynamics within this market category, thus allowing producers to pay more attention to the features most appreciated by consumers; generally speaking, in the Polish wine market most sales are off-the-shelf, while sales in wine shops are marginal, despite representing the most prestigious sales share. This implies a lack of consultation during the purchasing process - because there is no one who explains the particular characteristics of the product to you -, so brand reputation becomes very important in this context [61].

Producers should therefore focus their attention on the reputational attributes such as DO and brand. These characteristics should be stressed on the label to guarantee a direct connection with the consumer, because they are considered higher price features.

Since brand reputation is the critical success factor in this market, both the single and collective brands must enhance their prestige in order to increase sales volume. As also reported by Ferro and Benito Amaro [45] it is necessary to apply some collective action and public policies to improve terroirs' reputation.

In conclusion, despite the effectiveness of the hedonic model in explaining price diversification among products, few insights can be inferred about consumers' preferences. Further efforts should be made to outline the profile of possible buyers of sparkling wines in the Polish market.

A limitation of the results could be the restricted area of investigation, just the off-trade channel, being the main channel for wine in Poland. In fact, the dataset doesn't take into account wines sold through the HoReCa channel that could further moderate the value of reputational attributes [6] and gain additional insight on the premium price in this iconic wine sector. Further research should be conducted in order to better understand consumer behaviour in the on-trade channel.

\section{ACKNOWLEDGEMENTS}

We thank the anonymous reviewers for their careful reading of our manuscript and their many insightful comments and suggestions.

\section{REFERENCES}

[1] OIV (2019a), State of the vitiviniculture world market: State of the sector in 2018, available at: http:// www.oiv.int/public/medias/6679/en-oiv-state-of-thevitiviniculture-world-market-2019.pdf.

[2] OIV (2019b), 2019 Statistical Report on World Vitiviniculture, available at: http://www.oiv.int/public/ medias/6782/oiv-2019-statistical-report-on-worldvitiviniculture.pdf.

[3] OIV (2018), 2018 World Vitiviniculture Situation. OIV Statistical Report on World Vitiviniculture, available at: http://www.oiv.int/public/medias/6371/oiv-statistical-report-on-world-vitiviniculture-2018.pdf.

[4] Euromonitor international, 2020. Retrieved from https://www.portal.euromonitor.com

[5] A. Chlebicka, J. Fałkowski, J. Lichota, From macro to micro: The change of trendsetters in the polish beer market, in Economic Perspectives on Craft Beer (2018) (pp. 295-319). Palgrave Macmillan, Cham.

[6] V. Boatto, E. Defrancesco, S. Trestini, The price premium for wine quality signals: Does retailers' information provision matter?, Br. Food J. 113 (2011) 669-679. https://doi.org/10.1108/00070701111131764.

[7] F. Caracciolo, L. Cembalo, E. Pomarici, The hedonic price for an Italian grape variety, Ital. J. Food Sci. 25 (2013), 289.

[8] P. Combris, S. Lecocq, M. Visser, Estimation of a Hedonic Price Equation for Bordeaux Wine: Does Quality Matter?, Econ. J. 107 (1997) 390-402. https:// doi.org/10.1111/j.0013-0133.1997.165. 
[9] A. María Angulo, J. María Gil, A. Gracia, M. Sánchez, Hedonic prices for Spanish red quality wine, Br. Food J. 102 (2000) 481-493. https://doi. org/10.1108/00070700010336445.

[10]M. Nerlove, Hedonic price functions and the measurement of preferences: The case of Swedish wine consumers, Eur. Econ. Rev. 39 (1995)1697-1716. https://doi.org/10.1016/0014-2921(95)00013-5.

[11]S. Trestini, E. Giampietri, S. Szathvary, A.D. Bianco, Insights on the Alleged Imitation of Prosecco Wine Name : The Case of the German Market, Int. J. Food Syst. Dyn. 9 (2018) 331-341.

[12] O. J. Parcero, E. Villanueva, World Wine Exports: What Determined the Success of the "New World" Wine Producers? American Association of Wine Economists, Working Paper $N^{\circ} 87.26$ p. (2011).

[13] L. Lockshin, A.M. Corsi, Consumer behaviour for wine 2.0: A review since 2003 and future directions, Wine Econ. Policy 1 (2012) 2-23. https://doi. org/10.1016/j.wep.2012.11.003.

[14]J. Rebelo, L.S. de M. Lourenço-Gomes, T. Gonçalves, J. Caldas, A hedonic price analysis for the portuguese wine market: Does the distribution channel matter?, J. Appl. Econ, 22 (2019) 40-59. https://doi. org/10.1080/15140326.2018.1550596.

[15] R. Carew, W.J. Florkowski, The Importance of Geographic Wine Appellations: Hedonic Pricing of Burgundy Wines in the British Columbia Wine Market, Can. J. Agric. Econ. Can. d'agroeconomie 58 (2010) 93-108. https://doi.org/10.1111/j.17447976.2009.01160.x.

[16]E. Pomarici, M. Lerro, P. Chrysochou, R. Vecchio, A. Krystallis, One size does (obviously not) fit all: Using product attributes for wine market segmentation, Wine Econ. Policy 6 (2017), 98-106. https://doi. org/10.1016/J.WEP.2017.09.001.

[17] A. Golan, H. Shalit, Wine quality differentials in hedonic grape pricing, J. Agric. Econ. 44 (1993) 311-321. https://doi.org/10.1111/j.1477-9552.1993.tb00274.x.

[18] E. Oczkowski, A hedonic price function for Australian premium table wine, Aust. J. Agric. Econ. 38 (1994) 93-110. https://doi.org/10.1111/j.1467-8489.1994. tb00721.x.

[19] M. Costanigro, J. McCluskey, R. Mittelhammer, Identifying Submarkets in the Wine Industry: a Multivariate Approach to Hedonic Regression, in: American Agricultural Economics Association Annual Meeting. Long beach California, (2006) p. 23.

[20] Orrego, M.J.E., Defrancesco, E., Gennari, A., 2012. The wine hedonic price models in the "Old and New World": state of the art. Rev. la Fac. Ciencias Agrar. 44(1), 205-220.
[21]P. Mora, Wine Positioning, Management for Professionals, Springer International Publishing, Cham. (2016) https://doi.org/10.1007/978-3-319-24481-5.

[22]P. Nelson, Advertising as Information, J. Polit. Econ. 82(1974) 729-754. https://doi.org/10.1086/260231.

[23]S. Landon, C.E. Smith, Quality Expectations, Reputation, and Price, South. Econ. J. 64 (1998) 628-647. https://doi.org/10.2307/1060783.

[24] G.J. Stigler, The economics of information, J. Political Econ. 69, (1961) 213-225.

[25] G. Schamel, K. Anderson, Wine Quality and Regional Reputation: Hedonic Prices for Australia and New Zealand, Econ. Soc. Aust. 412 (2003) 2016-25780.

[26] G. Schamel, Geography versus brands in a global wine market, Agribusiness 22 (2006) 363-374. https://doi.org/10.1002/agr.20091

[27] M. Costanigro, J.J. McCluskey, The Economics of Nested Names: Name Specifity, Reputation and price premia, Am. J. Agric. Econ. 92 (2010) 13391350. https://doi.org/10.1093/ajae/aaq065

[28]F. Caracciolo, M. D’Amico, G. Di Vita, E. Pomarici, A. Dal Bianco, L. Cembalo, Private vs. collective wine reputation, Int. Food. Agribus. Man. 19 (2016) 191210. 10.22004/ag.econ.244704

[29] L. Rossetto, G. Gastaldello, The Loyalty Structure of Sparkling Wine Brands in Italy, J. Wine. Econ., 13 (2018) 409-418. DOI: https://doi.org/10.1017/ jwe. 2018.43

[30]N. Verdonk, J. Wilkinson, J. Culbert, R. Ristic, K. Pearce, K. Wilkinson, Toward a model of sparkling wine purchasing preferences, Int. J. Wine Bus. Res. 29 (2017) 58-73. https://doi.org/10.1108/IJWBR-10-2015-0048

[31]E. Oczkowski, N. Pawsey, Community and Expert Wine Ratings and Prices, Econ. Paper Econ. Soc. Aust. 38 (2019) 27-40. https://doi.org/10.1111/17593441.12240

[32] H. Lee, D.A. Sumner, The Economic Value of Wine Names That Reference Place in the US Market: Analysis of "Champagne" and Sparkling Wine, (2013) In: Wine Economics pp. 73-87 Palgrave Macmillan, London.

[33] J.A. Culbert, R. Ristic, L.A. Ovington, A.J. Saliba, K.L. Wilkinson, Influence of production method on the sensory profile and consumer acceptance of Australian sparkling white wine styles. Aust. J. Grape Wine R. 23 (2017), 170-178. https://doi.org/10.1111/ajgw.12277

[34] R. Vecchio, M.T. Lisanti, F. Caracciolo, L. Cembalo, A. Gambuti, L. Moio, T. Siani, G. Marotta, C. Nazzaro, P. Piombino, The role of production process and information on quality expectations and perceptions of sparkling wines. J. Sci. Food Agric. 99 (2019), 124135. https://doi.org/10.1002/jsfa.9153 
[35]G. V. Jones, K.H. Storchmann, Wine market prices and investment under uncertainty: an econometric model for Bordeaux Crus Classes, Agric. Econ. 26 (2001) 115-133. https://doi. org/10.1111/j.1574-0862.2001.tb00058.x.

[36] L. Benfratello, M. Piacenza, S. Sacchetto, Taste or reputation: what drives market prices in the wine industry? Estimation of a hedonic model for Italian premium wines. Appl. Econ. 41(2009) 2197-2209. https://doi.org/10.1080/00036840701222439.

[37] S. Lecocq, M. Visser, What determines wine prices: Objective vs. sensory characteristics, J. Wine Econ. 1(2006) 42-56. https://doi.org/10.1142/9789813232747_0023.

[38] K.J. Lancaster, A New Approach to Consumer Theory, J. Political Econ 74 (1966) 132-157.

[39] S. Rosen, Hedonic Prices and Implicit Markets: Product Differentiation in Pure Competition, J. Political Econ. 82 (1974) 34-55.

[40] M. Boland, T. Schroeder, Marginal Value of Quality Attributes for Natural and Organic Beef, J. Agric. Appl. Econ. 34 (2016) 39-49. https://doi.org/10.1017/ s1074070800002133

[41] K.B. Maguire, N. Owens, N.B. Simon, The price premium for organic babyfood: A hedonic analysis, J. Agric. Resour. Econ. 29 (2004) 132-149.

[42] A. Bonanno, A Hedonic Valuation of Health and Nonhealth Attributes in the U.S. Yogurt Market, Sci. Agribus. 32 (2016) 299-313. https://doi.org/10.1002/agr.

[43]S.M. León, Determinación de precios inmobiliarios en caba y efectos de política de transporte: modelos espaciales y evaluación de impacto, (2016) (Doctoral dissertation, Universidad del CEMA (UCEMA)).

[44] G.E.P. Box, D.R. Cox, An Analysis of Transformations, Journal of the Royal Statistical Society: Series B (Methodological), 26 (1964) 211-243.

[45] G. Ferro, I. Benito Amaro, What factors explain the price of top quality wines?, Int. J. Wine Bus. Res. 30 (2018) 117-134. https://doi.org/10.1108/IJWBR-05-2017-0036-.

[46] L. Rossetto, L. Galletto, Retail strategies for rosé wines in Italy: a hedonic price analysis. Int. J. Wine Bus. Res. 31 (2019) (3) 282-302. IJWBR-03-2018-0013. https://doi.org/10.1108/IJWBR-03-2018-0013.

[47] H.H. Ali, C. Nauges, The Pricing of Experience Goods: The Example of en primeur Wine, Am J Agr Econ, 89 (2016) 91-103. https://doi.org/10.1111/ j.1467-8276.2007.00965.x.

[48]B.E. Steiner, Australian wines in the British wine market: A hedonic price analysis, Agribusiness 20 (2004) 287-307. https://doi.org/10.1002/agr.20012.

[49] M.R. O’Brien, Model-dependent variance inflation factor cutoff values, Qual. Quant. 41 (2007) 673-690.
https://doi.org/10.1081/QEN-120001878

[50]T. S. Breusch, A. R. Pagan, A simple test for heteroscedasticity and random coefficient variation, Econometrica, (1979) 1287-1294. DOI: 10.2307/1911963

[51]H. White, A heteroskedasticity-consistent covariance matrix estimator and a direct test for heteroskedasticity, Econometrica (1980) 817-838. DOI: $10.2307 / 1912934$

[52]L. Cembalo, C. Gianni, D.G. Teresa, S. Riccardo, C. Tagliafierro, Beyond Agropiracy: The Case of Italian Pasta in the United States Retail Market, Agribusiness 24 (2008) 403-413. https://doi.org/10.1002/agr.

[53]L. Martínez-Carrasco Martínez, M. Brugarolas MolláBauzá, F.J. Del Campo Gomis, A. Martínez Poveda, Influence of purchase place and consumption frequency over quality wine preferences, Food Qual. Prefer. 17 (2006) 315-327. https://doi.org/10.1016/j. foodqual.2005.02.002.

[54] G. Di Vita, F. Caracciolo, L. Cembalo, E. Pomarici, M. D’Amico, Drinking wine at home: Hedonic analysis of sicilian wines using quantile regression, Am. J. Appl. Sci.12 (2015) 679-688. DOI: 10.3844/ ajassp.2015.679.688

[55]M. Cerjak, M. Tomić, N. Fočić, R. Brkić, The importance of intrinsic and extrinsic sparkling wine characteristics and behavior of sparkling wine consumers in Croatia. J. Int. Food Agribus. Mark. 28 (2016) 191201. https://doi.org/10.1080/08974438.2015.1053162

[56]S. Müller, The country-of-origin effect of sparkling wine. 3rd International Wine Business Research Conference, Montpellier, 6-7-8 July, 2006.

[57]R. Cooper, T.W. Ross, Prices, Product Qualities and Asymmetric Information: The Competitive Case, Rev. Econ. Stud. 51(2006) 197-207. https://doi. org/10.2307/2297687.

[58] G. Di Vita, G. Pappalardo, G. Chinnici, G. La Via, M. D’Amico, Not everything has been still explored: Further thoughts on additional price for the organic wine. J. Clean. Prod. 231 (2019), 520-528. https://doi. org/10.1016/j.jclepro.2019.05.268

[59]L. Onofri, V. Boatto, A. Dal Bianco, Who likes it "sparkling"? An empirical analysis of Prosecco consumers' profile. Agri. Food Econ. 3 (2015), 11. 10.1186/s40100-014-0026-x

[60] P.E. Kennedy (1981), Estimation with correctly interpreted dummy variables semilogarithmic equations [the interpretation of dummy variables in semilogarithmic equations]. Am. Econ. Rev. 71(1981), 801-801.

[61]L. Cembalo, F. Caracciolo, E. Pomarici, Drinking cheaply: The demand for basic wine in Italy, Aust. J. Agric. Resour. Econ. 58 (2014) 374-391. https://doi. org/10.1111/1467-8489.12059. 